\title{
IMPACT OF MONETARY AND FISCAL POLICIES ON INCOME INEQUALITY IN EUROPEAN MONETARY UNION
}

\author{
İmre ERSOY* \\ Bilgehan BAYKAL ${ }^{* *}$ \\ Pinar DENIZ ${ }^{* * *}$
}

\section{Abstract:}

The article investigates the relationship between ECB's monetary policy, $S G P$ constrained fiscal policies of EMU members, the growth levels and the members' social development pattern embodied as income distribution. Panel cointegration analysis is employed for the period between 1999 and 2008 in search for the impact of economic and monetary unification of the first 12 EMU members on the increasing income inequality. The results of the empirical analysis show that both the monetary policy of $E C B$ and the restrained fiscal policies of the EMU members have negative effects on income equality. The findings also suggest that growth has positive effect on income distribution but the pace of GDP growth is declining in EMU.

Keywords: Monetary Policy, Fiscal Policy, Income Distribution, Models with Panel Data

özet:

Bu çalışma Avrupa Merkez Bankası'nın (AMB) para politikası, Ekonomik ve Parasal Birliğe (EPB) üye ülkelerin Büyüme ve İstikrar Paktı kuralları çerçevesinde uyguladıklarl maliye politikaları ve büyüme seviyeleri ile ülkelerin sosyal kalkınma modelinin göstergesi olan gelir dağılımı arasındaki ilişkiyi araştırmaktadır. EPB oluşumunun ilk 12 üyenin

\footnotetext{
*Asst. Prof. (PhD), Marmara University, European Union Institute, Department of EU Economics

${ }^{* *} \mathrm{PhD}$ Candidate, Marmara University, European Union Institute, Department of EU Economics

${ }^{* * *}$ MA Student, Marmara University, Faculty of Economics and Administrative Sciences, Department of Economics
} 
artan gelir dağılımı adaletsizliği üzerindeki etkilerini araştırmak için 1999 ile 2008 yıllarını kapsayan dönem için panel koentegrasyon analizi uygulanmıştır. Ampirik çalışmanin sonuçları, hem AMB'nın para politikasının hem de EPB üyelerinin kontrol altındaki maliye politikalarının gelir dağılımı üzerindeki olumsuz etkilerini göstermektedir. Sonuçlar ayrıca, büyümenin gelir dağılımını olumlu etkilediğini göstermektedir ancak EPB'in büyüme hizl da düşmektedir.

Anahtar Kelimeler: Para Politikası, Maliye Politikası, Gelir Dağılımı, Panel Veri Modelleri

\section{Introduction}

The relationship between economic growth and income distribution has been the subject of debate for decades. The theory developed by Kuznets (1955) argues that there is a positive relationship between the income inequality and growth until a certain development level where the relationship starts to reverse as shown by the Kuznets curve.

Figure 1: Kuznets Curve

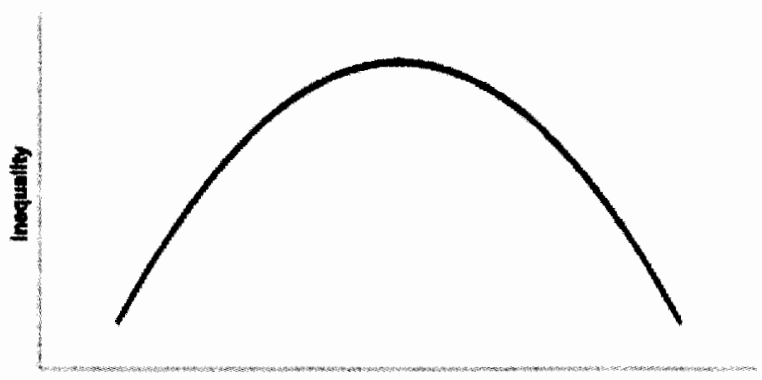

heome per capse

The results of empirical findings on the relationship between growth and income equality are rather inconclusive. Keefer and Knack (1999), Deininger and Lyn Squire (1996), Perotti (1996), Weede (1997), Bourguignon and Verdier (2000) analyzed the effect of inequality on 
income growth and obtained diverse findings. Deininger and Lyn Squire (1998) argue that asset inequality lowers income growth for the poor; however this is not the case for the rich. For the causality relationship from growth to income equality, Lucas (2004) argues that increasing production helps reduce income inequality. However, Cordoba and Verdier (2008) find that people are willing to sacrifice growth in order to reduce inequality.

Romer and Romer (1998) argue that there are several channels, long-run and short-run, attaching income distribution to inflation that is created by monetary policy. They state that decline in the real value of wages and transfers due to inflation affects poor negatively. Bulir and Gulde (1995) also find that both inflation and its variability deteriorate the income distribution. Pryor (2007) also argues that the most important reason for the increase in income inequality is the rising inequality of property incomes including the interest rates. Li, Xie, Zou (2000), employing an unbalanced panel data within the period 1950-1992 for many developed and developing countries, argue that income taxation and government spending lower income inequalities. They also analyze Kuznets curve theory and verify it for the middle-to-low-income sample, but not for the high-income sample.

In the EMU-12, the Gini coefficient, which is an indicator of inequality of income distribution increased from 28 in 2000 to 30 in $2007 .^{1}$ In the euro-zone, monetary policy is implemented by European Central Bank (ECB), whose primary objective is to maintain price stability. The Stability and Growth Pact (SGP) envisages a balanced budget for the normal times and a maximum of $3 \%$ budget deficit to GDP in problematic conjunctures and a maximum of $60 \%$ Public Sector Borrowing to GDP ratio for the EMU (Economic and Monetary Union) members. The growth rate of members since the start of EMU has been, on average, lower than both the USA and $\mathrm{UK}^{2}$ This study investigates the effect of monetary policy, fiscal policies and growth on income distribution in Euro-zone employing panel cointegration analysis. Section 2 explains the methodology and the dataset

\footnotetext{
${ }^{1}$ Eurostat, Inequality of income distribution Gini coefficient updated on 29 April 2008

2 The growth rates for $1999-2008$ in EMU are (in \%) 2,9, 3,9, 1,9, 0,9, 0,8, 2,1, $1,7,3,0,2,7,0,7$ whereas for U.K $3,5,3,9,2,5,2,1,2,8,3,0,2,2,2,9,2,6,0,6$ and for US $4,8,4,1,1.1,1.8,2,5,3,6,3,1,2,7,2,1,0,4$
} 
employed. Section 3 portrays and discusses the empirical findings. Section 4 concludes.

\section{Methodology and Dataset}

There are various methodologies to measure economic inequality, like Theil Index, GINI index, or lowest, highest relevant percentiles of income distribution, among others. In this paper, GINI index is employed.

\subsection{Dataset}

Annual data is used for 1999-2008 for 12 EMU countries. ${ }^{3}$ GINI coefficients are found with some missing values, however via interpolation technique the data is extended to the relevant time period chosen. GINI coefficients, Budget Balance, GDP growth and Interest rates- as Open Market Operation (refinancing operation) - data are obtained from source sites; UNDP, Worldbank, Eurostat and ECB website. Inflation values are collected from OECD website as annual CPI inflation rate and converted. Real interest rates are obtained for each country. ${ }^{4}$ Annual Budget Balance values are divided by GDP values. ${ }^{5}$

\subsection{Methodology}

The paper employs Im, Pesaran and Shin (2003, hereafter IPS) panel unit root test, Pedroni (1999) panel cointegration test and Pedroni (2000) Panel Fully Modified OLS tests.

\subsubsection{Panel Unit Root Test}

IPS (2003) test has unit root in the null hypothesis and allows for heterogeneity of the autoregressive coefficient. The test has the alternative hypothesis that a fraction of the series in the panel is stationary. In order to

${ }^{3}$ First 12 EMU countries are namely; Austria, Belgium, Finland, France, Germany, Greece, Ireland, Italy, Luxembourg, Netherlands, Portugal and Spain.

${ }^{4}$ Real interest rates are obtained by using the equation:

$$
1+r_{r}=\frac{1+i_{i}}{1+\pi i}
$$

5 The following abbreviations are used for the variables; GINI (GINI coefficients), INT (Real interest rates of OMO refinancing operations), BB (Budget Balance divided by GDP), Growth (GDP growth rate). 
calculate the statistics, IPS test requires the cross-sectional units to be balanced.

$$
\Delta Y_{i, t}=\alpha_{i}+\rho_{i} Y_{i, s-1}+\sum_{k=1}^{n} \varphi_{k} \Delta Y_{i, t-k}+\lambda_{i} t+\delta_{t}+\varepsilon_{i r} \quad i=1, \ldots, \mathrm{N} \quad \mathrm{t}=1, \ldots, \mathrm{T}
$$

\subsubsection{Panel Cointegration Test}

Pedroni (1999) tests are cointegration tests for panel data. Pedroni has created seven tests to check cointegration. There is no cointegration in the null hypothesis of Pedroni tests. Thus, in order to say that there is panel cointegration, we have to reject the null hypothesis. Pedroni panel cointegration test allows for heterogeneity in the errors across cross sectional units and also allows for the cointegrating vector to vary. The seven tests also include panel unit root tests. The seven tests Pedroni created are below:

The panel $v$-statistic:

$$
T^{2} N^{3 / 2} Z_{\hat{v} N, T} \equiv T^{2} N^{3 / 2}\left(\sum_{i=1}^{N} \sum_{t=1}^{T} \hat{L}_{1 I i}^{-2} \hat{e}_{i, t-1}^{2}\right)^{-1}
$$

The panel $\rho$-statistic:

$$
T \sqrt{N} Z_{\dot{\rho} N, T} \equiv T \sqrt{N}\left(\sum_{i=1}^{N} \sum_{i=1}^{T} \hat{L}_{11}^{-2} \hat{e}_{i, t-1}^{2}\right)^{-1} \sum_{i=1}^{N} \sum_{i=1}^{T} \hat{L}_{11 i}^{-2}\left(\hat{e}_{i z-1} \Delta \hat{e}_{i, t}-\hat{\lambda}_{i}\right)
$$

The panel t-statistic (non-parametric):

$$
Z_{t N, T} \equiv\left(\tilde{\sigma}_{N, T}^{2} \sum_{i=1}^{N} \sum_{t=1}^{T} \hat{L}_{11 i}^{-2} \hat{e}_{i, t-1}^{2}\right)^{-1 / 2} \sum_{i=1}^{N} \sum_{t=1}^{T} \hat{L}_{11 i}^{-2}\left(\hat{e}_{i, t-1} \Delta \hat{e}_{i, t}-\hat{\lambda}_{i}\right)
$$


The panel t-statistic (parametric):

$$
Z_{i N, T}^{*} \equiv\left(\tilde{s}_{N, T}^{*} \sum_{i=1}^{N} \sum_{t=1}^{T} \hat{L}_{11 i}^{2} \hat{e}_{i, t-1}^{* 2}\right)^{-1 / 2} \sum_{i=1}^{N} \sum_{i=1}^{T} \hat{L}_{11 i}^{-2}\left(\hat{e}_{i, t-1}^{*} \Delta \hat{e}_{i, t}^{*}\right)
$$

The group $\rho$-statistic:

$$
T N^{-1 / 2} \widetilde{Z}_{\not N, T-1} \equiv T N^{-1 / 2} \sum_{i=1}^{N}\left(\sum_{t=1}^{T} \hat{e}_{i, t-1}^{2}\right)^{-1} \sum_{i=1}^{T}\left(\hat{e}_{i, t-1} \Delta \hat{e}_{i, t}-\hat{\lambda}_{i}\right)
$$

The group t-statistic (non-parametric):

$$
N^{-1 / 2} \tilde{Z}_{t, T-1} \equiv N^{-1 / 2} \sum_{i=1}^{N}\left(\hat{\sigma}_{i}^{2} \sum_{i=1}^{T} \hat{e}_{i, t-1}^{2}\right)^{-1 / 2} \sum_{i=1}^{T}\left(\hat{e}_{i, t-1} \Delta \hat{e}_{i, t}-\hat{\lambda}_{i}\right)
$$

The group t-statistic (parametric):

$$
N^{-1 / 2} \widetilde{Z}_{u, T}^{*} \equiv N^{-1 / 2} \sum_{i=1}^{N}\left(\sum_{i=1}^{T} \hat{s}_{i}^{* 2} \hat{e}_{i, t-1}^{*}\right)^{-1 / 2} \sum_{i=1}^{T}\left(\hat{e}_{i, t-1}^{*} \Delta \hat{e}_{i, t}^{*}\right)
$$

\subsubsection{Panel Fully Modified OLS test}

Pedroni (2000), basing on Philips and Hansen (1990) paper proposed a Fully Modified OLS approach for homogenous cointegration vectors to get estimates, by presenting an FMOLS group mean estimator. In the null hypothesis, there is a common value for the cointegrating vector. In the alternative hypothesis, the cointegrating vector need not be common. The FMOLS group mean estimator is simply the average value of the individual FMOLS estimates. 


\section{Findings and Discussions}

In this study, we employed BB, Growth and INT together as regressors of GINI. However, it is probable to have multicollinearity between BB and Growth since government expenditures are observed in national income model and accordingly an increase in government expenditures lead to increase in GDP and contribute to Growth. In order to overcome this problem, we employed two more regressions with regressor; (1) Growth and INT, (2) BB and INT. Hence, we will not only eliminate the priori problem of multicollinearity, but also check the robustness of the analysis. In Table 1 , we have the results of panel unit root test, IPS test for constant and constant-trend case.

Table 1: Panel Unit Root Test

\begin{tabular}{|c|c|c|}
\hline \multirow{2}{*}{} & \multicolumn{2}{|c|}{ IPS Unit Root Test } \\
\cline { 2 - 3 } & Constant & Constant and Trend \\
\hline GINI & $-1.544(0.061)$ & $0.045(0.518)$ \\
\hline BB & $-0.861(0.194)$ & $1.076(0.859)$ \\
\hline Growth & $-1.461(0.072)$ & $0.095(0.537)$ \\
\hline ENT & $-2.106(0.017)$ & $-0.316(0.375)$ \\
\hline
\end{tabular}

Note: Max lag is chosen as 2. Modified Hannan Quinn Criterion is used for automatic lag selection. The values in brackets are p-values.

We fail to reject the null of unit root, since the probability values are given in brackets are higher than 5\% significance level. After we obtain the result that the variables are unit root, we can continue to the panel cointegration tests. In Table 2, we have Pedroni panel cointegration test for all three regressions. First of all, we check the regression with the regressors; BB, Growth and INT. As we mentioned before, Pedroni panel cointegration test has no cointegration in the null hypothesis. The test shows that we reject the null within 5\% significance level. Afterwards, we apply cointegration test for the second regression with the regressors; BB and INT. The test displays the existence of cointegration again. Lastly, the third regression with the regressors; Growth and INT, shows that except for panel rho statistic, all six test rejects the null hypothesis. 
Table 2: Pedroni Panel Cointegration Test

\begin{tabular}{|c|c|c|c|}
\hline Tests & BB - Growth - INT & BB - NT & Growth - INT \\
\hline Panel v-Statistic & $-3.055(0.003)$ & $-3.026(0.004)$ & $-2.651(0.011)$ \\
\hline Panel rho-Statistic & $3.241(0.002)$ & $2.224(0.033)$ & $1.639(0.104)$ \\
\hline Panel PP-Statistic & $-7.290(0.000)$ & $-6.216(0.000)$ & $-5.169(0.000)$ \\
\hline Panel ADF-Statistic & $-6.050(0.000)$ & $-4.255(0.000)$ & $-5.876(0.000)$ \\
\hline Group rho-Statistic & $4.218(0.000)$ & $3.330(0.001)$ & $3.168(0.002)$ \\
\hline Group PP-Statistic & $-10.295(0.000)$ & $-7.870(0.000)$ & $-6.795(0.000)$ \\
\hline Group ADF-Statistic & $-6.931(0.000)$ & $-4.328(0.000)$ & $-5.168(0.000)$ \\
\hline
\end{tabular}

Note: Max lag is chosen as 2. Constant and Trend case is selected. The values in brackets are p-values.

After showing the existence of panel cointegration for all three regressions, we estimate the coefficients using FMOLS technique. In Table 3, we have FMOLS results.

Table 3: FMOLS results

\begin{tabular}{|c|c|c|c|c|c|c|}
\hline \multicolumn{2}{|c|}{ Regression BB - Growth - INT } & \multicolumn{2}{c|}{ Regression: BB - INT } & \multicolumn{2}{c|}{ Regression: Growth - INT } \\
\hline BB & Growth & INT & BB & INT & Growth & INT \\
\hline 0.11 & -0.20 & $\begin{array}{c}0.07 \\
(-9.08)\end{array}$ & $\begin{array}{c}0.18 \\
(-5.14)\end{array}$ & $\begin{array}{c}0.33 \\
(-1.07)\end{array}$ & $\begin{array}{c}-0.06 \\
(-12.43)\end{array}$ & $\begin{array}{c}0.19 \\
(-7.12 .82)\end{array}$ \\
\hline
\end{tabular}

Note: $\mathrm{N}=12, \mathrm{~T}=10, \max -\mathrm{lag}=1$, Constant - trend case is employed. The values in brackets are the t-statistics

All of the estimates are significant since the t-statistics given in brackets are higher than the $5 \%$ critical values. First regression shows that $\mathrm{BB}$ and INT seem to affect GINI positively and Growth affects GINI negatively. ${ }^{6}$

${ }^{6} \mathrm{~A}$ positive (negative) effect on GINI indicates positive (negative) effect on income inequality 
As we have mentioned before, to avoid the priori existence of multicollinearity between BB and Growth, we split the regression into two new regressions. The second regression displays that both $\mathrm{BB}$ and INT have positive effects on GINI. Lastly, the third regression shows that Growth has a negative and INT has a positive effect on GINI. The FMOLS results for the two new regressions are consistent with the first regression that includes all variables. Hence, we can argue that the findings are robust.

The results we obtained are also found to be consistent with the theoretical basis. FMOLS results show that BB affects GINI positively. We can attribute this positive sign to the mechanism that whether the increase in the budget balance is achieved through the increase in tax payments or the decrease in the government expenditures, income going to the low income groups will be deteriorated. Thus, income equality will be harmed and accordingly GINI index will increase.

The effect of Growth is found to be negative in both regressions. The countries we employ are developed countries. Accordingly, we can argue that these countries probably have crossed the critical boundary in the Kuznets curve. Hence, the increase in the per capita income will refer to the improvement in income distribution.

Both regressions show that INT has a positive effect on GINI. We attribute this to the theoretical framework that high income groups have income higher than their subsistence level and direct some amount to investment. Thereby, they are able to earn extra income/wealth. This process widens the income gap between low and high income groups.

\section{Conclusions}

European Economic and Monetary Union has been successful not only in economic, monetary and financial unification of the now 16 members but also in the international arena. However, since its establishment EMU shows an increase in income inequality. The empirical analysis between 1999 and 2008 for the first 12 members of EMU shows that the monetary policy of the hard-nosed ECB and the SGP restrained fiscal policies of the members have positive effect on the increase in income inequality in EMU. The empirical findings also suggest that growth has negative effect on income inequality in euro zone, a result which is in line with the Kuznets 
curve. The problem in EMU, however, is that there is also a decline in GDP growth compared to non-EMU EU members like U.K and also USA.

The SGP should be again revised to bring more flexibility to budget deficits and to take not only stability but also growth into account. The conservative ECB policy aimed at price stability by focusing on money supply and economic-financial indicators should watch more closely the developments in terms of increasing income inequality in EMU. 


\section{References:}

Bourguignon, F., \& Verdier, T. (2000). Oligarchy, democracy, inequality and growth. Journal of Development Economics, 62, 285-313.

Bulir, A., \& Gulde, A.-M. (1995). Inflation and Income Distribution: Further Evidence on Empirical Links. International Monetary Fund Working Paper, No. 95/86. Retrieved: September 17, 2008, from http://papers.ssrn.com/sol3/papers.cfm?abstract_id $=883233$

Cordoba, J. C., \& Verdier, G. (2008). Inequality and growth: Some welfare calculations. Journal of Economic Dynamics \& Control, 32, 1812-1829.

Deininger, K., \& Squire, L. (1996). Measuring income inequality: a new data-base. World Bank Economic Review, 10, 565-591.

Deininger, K., \& Squire, L. (1998). New ways of looking at old issues: inequality and growth. Journal of Development Economics, 57, 259-287.

Im, K. S., Pesaran, M. H., \& Shin, Y. (2003). Testing for Unit Roots in Heterogeneous Panels. Journal of Econometrics, 115, 53-74.

Keefer, P., \& Knack, S. (1999). Polarization, Politics, and Property Rights: Links between Inequality and Growth. World Bank Policy Research Working Paper No. 2418. Retrieved: September 18, 2008, from http://ssrn.com/abstract=632489

Kuznets, S. (1955). Economic Growth and Income Inequality. The American Economic Review, 45, 1-28.

Li, H., Xie, D., \& Zou, H.-F. (2000). Dynamics of Income Distribution. The Canadian Journal of Economics, 33, 937-961.

Lucas, R. E. (2004). The industrial revolution: past and future. The Region, 18, 5-20. Retrieved: September 24, 2008, from http://minneapolisfed.org/pubs/region/04-05/essay.cfm

Moran, T. P. (2005). Kuznets's Inverted U-Curve Hypothesis: The Rise, Demise, and Continued Relevance of a Socioeconomic Law. Sociological Forum, 20, 209-244.

Pedroni, P. (1999). Critical Values for Cointegration Tests in Heterogeneous Panels with Multiple Regressors. Oxford Bulletin of Economics and Statistics, Special Issue, 653-670. 
Pedroni, P. (2000). Fully Modified OLS for Heterogeneous co integrated Panels. Nonstationary Panels, Panel Cointegration and Dynamic Panels, 15, 93-130.

Perotti, R. (1996). Growth, income distribution and democracy: what the data say. Journal of Economic Growth, 1, 149-187.

Phillips, P. C. B., \& Hansen, B. E. (1990). Statistical inference in instrumental regressions with I(1) processes. Review of Economic Studies, 57, 99-125.

Pryor, F. L. (2007). The anatomy of increasing inequality of U.S. family incomes. The Journal of Socio-Economics, 36, 595-618.

Romer, C. D., \& Romer, D. H. (1998). Monetary Policy And The WellBeing Of The Poor. NBER Working Paper No. W6793. Retrieved: September 20, 2008, from http://ssrn.com/abstract=139571

Weede, E. (1997). Income inequality, democracy and growth reconsidered. European Journal of Political Economy, 13, 751-764. 